\title{
A checklist of Diptera collected in the Caña de Azúcar morgue of Aragua, Venezuela
}

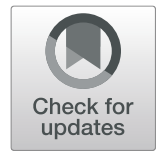

José Nuñez Rodríguez ${ }^{1}$, Mary Bonilla Villarreal ${ }^{2}$ and Jonathan Liria ${ }^{3^{*}}$

\begin{abstract}
Background: Venezuela has experienced soaring rates of violent crime, in particular, homicides. The Aragua state with 142 to 168 crimes per 100,000 inhabitants has the highest homicide rate in the last 5 years. All these cases are transferred to the estate morgue. Entomological evidence on cadavers has been used as a tool to clarify the death causes. Due to this, we analyzed the occurrence of forensically important dipteran species on facilities of the Caña de Azúcar morgue in Aragua, Venezuela.

Findings: A total of 692 adult insects belonging to five species of Calliphoridae and Muscidae were collected at the Caña de Azúcar morgue premises (body holding area and autopsy room). Chrysomya megacephala and Musca domestica were the most frequent species in the morgue areas. Other species with forensic importance were also found: Lucilia cuprina, Chrysomya albiceps, and Ophyra aenescens.
\end{abstract}

Conclusions: The results could be used as additional sources of information in Venezuelan criminal investigations.

Keywords: Chrysomya megacephala, Musca domestica, Necrophagous insects, Blow flies, Forensic entomology

\section{Main text}

Human bodies suffer a series of physicochemical and microbiological changes that modify their anatomy. When necrophagous insects accelerate the decomposition process, it results to a difficulty for the forensic pathologist to establish the death cause. However, entomological evidence on cadavers has been used as a tool in criminal investigations such as clarifying the death causes, geographical location, and eventually transfer of the body (Smith 1986; González et al. 2011; Nuñez 2012).

The entomologist's work begins when there is entomological evidence, which requires a specialized study of the species involved, stage of development in which the insect was collected, life cycle, and other aspects of its biology. When obtaining this data, it is sought to provide information within the forensic context: primary species colonizer, ecological succession, development at the

\footnotetext{
* Correspondence: jonathan.liria@gmail.com

${ }^{3}$ Grupo de Población y Ambiente, Universidad Regional Amazónica Ikiam,

Tena, Napo, Ecuador

Full list of author information is available at the end of the article
}

temperature of the event site, geographical location, and environmental factors help to estimate the minimum postmortem interval (mPMI), as well as other circumstances regarding the cause of death (Gennard 2007; Amendt et al. 2010).

Venezuela has experienced soaring rates of violent crime, in particular, homicides (Tremaria 2016; UNODC 2019). Data regarded from a non-governmental organization known as the Venezuelan Violence Observatory provides information on homicide rates and showed that the Aragua state presents the highest homicide rate in the last 5 years (142 to 168 crimes per 100 , 000 inhabitants). All these cases are transferred to the estate morgue, located in Caña de Azúcar neighborhood at $130 \mathrm{~km}$ from the Caracas. This morgue has two main spaces: the body holding area with mortuary refrigerators for storage and the autopsy room area. However, since 2015, the refrigerators are only partially operational and serve for short-term storage only. Thus, all bodies are placed in the autopsy room in postmortem tables. After, autopsy unclaimed bodies are returned temporarily to the mortuary refrigerators. Under these 
conditions, some sarcosaprophagous Diptera species colonized some exposed bodies in the morgue area facilities.

From an entomological point of view, in Aragua state are recorded 36 flies species (23 Calliphoridae and 13 Muscidae), with eight species reported in forensic studies: Calliphora vicina Robineau-Desvoidy, 1830, Chrysomya albiceps (Wiedemann, 1819), C. megacephala (Fabricius, 1794), Lucilia sericata (Meigen, 1826), L. cluvia (Walker, 1849), L. cuprina (Wiedemann, 1830), Cochliomyia macellaria (Fabricius, 1775), and Musca domestica Linnaeus, 1758 (Cova-García 1964; Magaña et al. 2006; Löwenberg-Neto and Carvalho 2013; Thomas 2014; Velásquez et al. 2017).

This study aims to characterize the Diptera species, particularly Calliphoridae and Muscidae, present on bodies that arrived for autopsy at the Caña de Azúcar morgue, Aragua. This investigation can contribute to the creation of a database of local dipterans species of medico-legal importance in Venezuela.

\section{Material and methods}

The study was done in the Caña de Azúcar morgue (CAM), located at $10^{\circ} 16^{\prime} 29.2^{\prime \prime}$ north latitude and $67^{\circ}$ 37' 17.3" west longitude, in the Mario Briceño Iragorry municipality of Aragua state. In CAM, two sites were selected: an autopsy room (AR) and a body holding area (BHA); in both sites were recorded temperature and relative humidity: $22.0{ }^{\circ} \mathrm{C} / 70.0 \%$ and $36.0^{\circ} \mathrm{C} / 52.1 \%$, respectively. The insects were collected in July 2016 from 10:00 to $12: 00 \mathrm{~h}$. The adult specimens were collected using entomological nets. In AR, the flies were sampled when flying around and resting in human corpses and medical instruments. There were also immature flies from a human male cadaver in chromatic stage, with larvae in the face and neck, which were collected. In BHA, the specimens were obtained resting in walls and the refrigerated cabinets. From a human male in saponification stage were collected adult flies. All adult flies were preserved in ethanol $70 \%$, while the immature stages were sacrificed in boiled water and preserved in ethanol $70 \%$ and the cephalopharyngeal skeleton was dissected and slide mounted (Sukontason et al. 2004). Finally, the specimens were taxonomically identified using dichotomic keys for adults (Amat et al. 2008; Carvalho and Mello 2008; Patitucci et al. 2013) and immatures (Florez and Wolff 2009; Velásquez et al. 2010).

\section{Results and discussion}

From the collected 692 adult specimens from Muscidae (78.2\%) and Calliphoridae (21.8\%), Musca domestica was the most abundant species (77.6\%), followed by Chrysomya megacephala (19.5\%), Lucilia cuprina (1.7\%), Ophyra aenescens (Wiedemann, 1830) (0.6\%), and
Chrysomya albiceps (0.6\%). In BHA, five species were registered, while in AH only two species were collected: C. megacephala and M. domestica (Table 1). From human corpses were collected 224 larvae identified as $C$. megacephala in the 2nd instar larvae with $8.0 \pm 0.19$ (7.1-8.6) $\mathrm{mm}$ mean length. The colonization initiated in natural cavities (mouth and nostrils) and the neck area associated with the autopsy Y-shaped incision, with 3day larvae development at $22{ }^{\circ} \mathrm{C}$.

Within dipterans of medico-legal importance, Calliphoridae is the taxa with most evidence in forensic entomology. Also, many other species have been described as primary colonizers of the human bodies and other experimental biomodels, even in cases of myiasis. This relationship is useful because it allows to estimate an interval from colonization of the body to its discovery, tracing minimum margins in the death data. This is achieved by taxonomic determination of the species of forensic importance, as well as their instar identification to establish the mPMI (Vanin et al. 2011; Thyssen et al. 2012; Ururahy et al. 2013). In this study, three Calliphoridae species were registered in the facilities of CAM, which coincides with previous entomological studies in the Aragua state (Magaña et al. 2006; Velasquez et al. 2017). The most abundant species C. megacephala is used as a model for developing techniques in medicocriminal forensic entomology (Gruner et al. 2017; Badenhorst and Villet 2018). In a similar investigation conducted in the Cali Institute of Legal MedicineColombia, the following species were reported: C. macellaria, C. megacephala, C. rufifacies (Macquart, 1842), and Musca domestica (Barreto et al. 2002). More recently, in the Judicial Morgue of the Institute of Legal Medicine of Panama city, Panama, the following species were reported: C. rufifacies, C. megacephala, C. macellaria, and Hemilucilia semidiaphana (Rondani, 1850); the latter was recorded associated to human bodies found in suburban and forested environments (Bermudez and Pachar 2010). Later, Costa-Oliveira and Vasconselos (2010) studied the Diptera associated with cadavers at the Institute of Legal Medicine of Recife city, Brazil. These authors reported five species present on cadavers:

Table 1 Adult Diptera species collected in the autopsy room and body holding area from the Caña de Azúcar morgue

\begin{tabular}{llll}
\hline Family & Species & \multicolumn{2}{l}{ Site/specimens collected } \\
\cline { 3 - 4 } & & $\mathrm{AR}$ & $\mathrm{BHA}$ \\
\hline Calliphoridae & Chrysomya megacephala & 96 & 39 \\
& C. albiceps & - & 4 \\
Muscidae & Lucilia cuprina & - & 12 \\
& Musca domestica & 216 & 321 \\
& Ophyra aenescens & - & 4
\end{tabular}

$A R$ autopsy room, $B H A$ body holding area 
C. albiceps, C. megacephala, C. macellaria, Oxysarcodexia riograndensis (Lopes, 1946), and Ravinia belforti (Prado \& Fonseca, 1932), these last two belonging to the Sarcophagidae family. In a recent study in the surroundings of the morgue Hospital in Puerto Cabello city, Venezuela, Lucilia cuprina, Lucilia eximia (Wiedemann, 1819), C. macellaria, C. albiceps, and C. megacephala (Nuñez et al. 2016) were found.

Some authors emphasized the importance of Muscidae species for mPMI estimation (Ramirez 2012); but this taxa and Sarcophagidae are little studied in Venezuela. In this study, the Muscidae species coincide with investigations carried out in Carabobo state (Liria 2006; Nuñez et al. 2016). Also, some investigations reported O. aenescens associated with the active decomposition process (Ramos et al. 2014; Mariani et al. 2014); also, this species was reported in urban areas and abundant in the dry season (Patitucci et al. 2010).

\section{Conclusion}

This study records five species of Calliphoridae and Muscidae present in the facilities of the judicial CAM. The BHA area showed high species richness and the AR area the lowest. Chrysomya megacephala and Musca domestica were the most abundant species recorded in both morgue areas. The checklist hereby provided can be used as a complementary source in Venezuelan criminal investigations.

\section{Abbreviations}

AR: Autopsy room; BHA: Body holding area; CAM: Caña de Azúcar morgue; mPMI: Minimum postmortem interval

\section{Acknowledgements}

We thank the staff of the Caña de Azúcar morgue for allowing access to the areas. Also, we thank PhD. Jan Spengler and two anonymous reviewers whose suggestions helped improve and clarify this manuscript.

\section{Adherence to national and international regulations} Not applicable.

\section{Authors' contributions}

JNR contributed to the idea of the research and the study design, collected the insects, and wrote the first article draft. MBV allowed access to the morgue facilities and collaborated with the first article draft. JL contributed to the final manuscript and revised the paper. The authors read and approved the final manuscript.

\section{Funding}

This research was not financially supported by any organization.

\section{Availability of data and materials}

Please contact the corresponding author for data requests.

\section{Ethics approval and consent to participate}

Not applicable.

\section{Consent for publication}

This study does not include publishing of personal data.

\section{Competing interests}

The authors declare that they have no competing interests.

\section{Author details}

'Departamento de Ciencias Morfológicas y Forenses, Escuela de Ciencias Biomédicas y Tecnológicas, Facultad de Ciencias de la Salud, Universidad de Carabobo, Valencia, Venezuela. ${ }^{2}$ Área de Antropología Forense del Servicio de Medicina y Ciencias Forenses, Maracay, Aragua, Venezuela. ${ }^{3}$ Grupo de Población y Ambiente, Universidad Regional Amazónica Ikiam, Tena, Napo, Ecuador.

Received: 14 October 2019 Accepted: 25 February 2020

Published online: 03 March 2020

\section{References}

Amat E, Vélez M, Wolff M (2008) Clave ilustrada para la identificación de los géneros y las especies de califóridos (Diptera: Calliphoridae) de Colombia. Caldasia 30:231-244

Amendt J, Lee M, Campobasso C, Grassberger M (2010) Current concepts in forensic entomology. Springer Dordrechet Heidelberg London New York.

Badenhorst R, Villet M (2018) The uses of Chrysomya megacephala (Fabricius, 1794) (Diptera: Calliphoridae) in forensic entomology. Forensic Sci Res 3:2-15. https://doi.org/10.1080/20961790.2018.1426136

Barreto M, Burbano ME, Barreto P (2002) Flies (Calliphoridae, Muscidae) and beetles (Silphidae) from human cadavers in Cali, Colombia. Mem Inst Oswaldo Cruz 97:137-138. https://doi.org/10.1590/S0074-02762002000100025

Bermúdez S, Pachar J (2010) Artrópodos asociados a cadáveres humanos en Ciudad de Panamá, Panamá. Rev Col Entomol 36:86-89

Carvalho C, Mello C (2008) Key to the adults of the most common forensic species of Diptera in South America. Rev Bras Entomol 52:390-406. https:// doi.org/10.1590/S0085-56262008000300012

Costa-Oliveira T, Vasconselos S (2010) Insects (Diptera) associated with cadavers at the Institute of Legal Medicine in Pernambuco, Brazil: implications for forensic entomology. Forensic Sci Int 198:97-102. https://doi.org/10.1016/j. forsciint.2010.01.011

Cova-García P (1964) Moscas de Venezuela. Cromográfica, Caracas, Venezuela

Florez E, Wolff M (2009) Descripción y clave de los estadios inmaduros de las principales especies de Calliphoridae (Diptera) de importancia forense en Colombia. Neotropical Entomol 38:418-429. https://doi.org/10.1590/S1519566X2009000300019

Gennard D (2007) Forensic entomology. An introduction. John Wiley \& Sons Ltd, The Atrium, Southern Gate, Chichester, England

González A, González L, Martínez I, Archilla F, Higuera J, Jiménez G (2011) Estimación del intervalo post-emersión de un cadáver hallado en un embalse en Granada (España). Cuad Med Forense 17:137-144. https://doi. org/10.4321/S1135-76062011000300005

Gruner SV, Slone DH, Capinera JL et al (2017) Volume of larvae is the most important single predictor of mass temperatures in the forensically important calliphorid, Chrysomya megacephala (Diptera: Calliphoridae). J Med Ent 54: 30-34. https://doi.org/10.1093/jme/tjw139

Liria J (2006) Insectos de importancia forense en cadáveres de ratas, CaraboboVenezuela. Rev Perú Med Exp Salud Pública 23:33-38

Löwenberg-Neto P, Carvalho CJB (2013) Muscidae (Insecta: Diptera) of Latin America and the Caribbean: geographic distribution and check-list by country. Zootaxa 3650:001-147. https://doi.org/10.11646/zootaxa.3650.1.1

Magaña C, Andara C, Contreras M et al (2006) Estudio preliminar de la fauna de insectos asociada a cadáveres en Maracay, Venezuela. Entomotropica 20:5359

Mariani R, García R, Varela G, Inda A (2014) Entomofauna of a buried body: study of the exhumation of a human cadaver in Buenos Aires, Argentina. Forensic Sci Int 237:19-26. https://doi.org/10.1016/j.forsciint.2013.12.029

Nuñez J (2012) Entomología forense en Venezuela. 1era edición. Editorial Livrosca, Caracas

Nuñez J, Liria J, Tocci N (2016) Dípteros de importancia forense en adyacencias de la morgue del Hospital Adolfo Prince Lara, Puerto Cabello. Edo. Carabobo-Venezuela. Salus 20:22-26

Patitucci L, Mulieri P, Olea S, Mariluis C (2013) Muscidae (Insecta: Diptera) of Argentina: revision of Buenos Aires province fauna, with a pictorial key to species. Zootaxa 3702:301-347. https://doi.org/10.11646/zootaxa.3702.4.1

Patitucci L, Mulieri P, Oliva A, Mariluis J (2010) Status of the forensically important genus Ophyra (Diptera: Muscidae) in Argentina. Rev Soc Entomol Argent 69: 91-99

Ramírez M (2012) Moscas Muscidae (Insecta: Diptera) en la entomología forense. Rev Fac Cs Forense y de la Salud 8:27-37 
Ramos Y, Velasquez A, Wolff M (2014) Preliminary study of insects associated to indoor body decay in Colombia. Rev Bras Entomol 58:326-332. https://doi. org/10.1590/s0085-56262014005000006

Smith K (1986) A manual of forensic entomology. The Trustees of the British Museum (Natural History) and Cornell University Press, New York

Sukontason K, Methanitikorn R, Sukontason KL, Piangjai S, Olson JK (2004)

Clearing technique to examine the cephalopharyngeal skeletons of blow fly larvae. J Vector Ecol 29:192-195

Thomas A (2014) Dinámica Estacional y Espacial de las Moscas verde-azules (Diptera: Calliphoridae) en un Gradiente Urbano-Rural en los altos mirandinos Venezolanos. Dissertation, Centro de Estudios Avanzados IVIC, Miranda, Venezuela

Thyssen P, Prado M, Uratani A, Lopes M (2012) Record of oral myiasis by Cochliomyia hominivorax (Diptera: Calliphoridae): case evidencing negligence in the treatment of incapable. Parasitol Res 111:957-959. https://doi.org/10. 1007/s00436-012-2856-3

Tremaria S (2016) Violent Caracas: understanding violence and homicide in contemporary Venezuela. Int J Conflict Violence 10:61-76

UNODC (2019) Global study on homicide. Homicide: extent, patterns, trends and criminal justice response. UN-Vienna. Available via: https://www.unodc.org/ documents/data-and-analysis/gsh/Booklet2.pdf Accessed 10 sep 2019

Ururahy A, Rafael J, Pujol J (2013) Temporal distribution of blowflies of forensic importance (Diptera: Calliphoridae), in man-size domestic pigs carcasses, in the Forest Reserve Adolpho Ducke, Manaus, Amazonas, Brazil. EntomoBrasilis 6:9-22. https://doi.org/10.12741/ebrasilis.v6i1.242

Vanin S, Gherardi M, Bugelli V, Di Paolo M (2011) Insects found on a human cadaver in central Italy including the blowfly Calliphora loewi (Diptera, Calliphoridae), a new species of forensic interest. Forensic Sci Int 207:e30e33. https://doi.org/10.1016/j.forsciint.2010.12.004

Velásquez Y, Magaña C, Martínez A, Rojo S (2010) Diptera of forensic importance in the Iberian Peninsula: larval identification key. Med Vet Entomol 24:1-16. https://doi.org/10.1111/j.1365-2915.2010.00879.x

Velásquez Y, Martínez-Sánchez Al, Thomas A, Rojo S (2017) Checklist and distribution maps of the blow flies of Venezuela (Diptera, Calliphoridae, Mesembrinellidae). ZooKeys 645:103-132. https://doi.org/10.3897/zookeys. 645.6972

\section{Publisher's Note}

Springer Nature remains neutral with regard to jurisdictional claims in published maps and institutional affiliations.

\section{Submit your manuscript to a SpringerOpen ${ }^{\circ}$ journal and benefit from:}

- Convenient online submission

- Rigorous peer review

- Open access: articles freely available online

- High visibility within the field

- Retaining the copyright to your article

Submit your next manuscript at $\boldsymbol{\nabla}$ springeropen.com 